\title{
O IMPOSSÍVEL VERIVÉRBIO: FAMIGERADO, DE G. ROSA, COMO ALEGORIA DO PODER SIMBÓLICO
}

\author{
FÁBIO BELO ${ }^{1}$ \\ Faculdade de Filosofia e Ciências Humanas - FAFICH \\ Universidade Federal de Minas Gerais - UFMG \\ Av. Pres. Antônio Carlos, 6627 - Pampulha, Belo Horizonte - MG, 31270-901
}

$\underline{\text { fabiobelo76@gmail.com }}$

Resumo. O conto Famigerado, de João Guimarães Rosa, lido a partir da teoria sociológica de Pierre Bourdieu, nos auxilia a demonstrar que a linguagem é um instrumento de dominação e violência. Criticamos a leitura do conto que defende a ideia de que o analfabetismo possa ser equivalente ao encontro mais primitivo com a palavra. Insistimos na tese de que o poder simbólico perpassa as relações de poder, constituindo-as e mantendo-as. Concluímos sustentando a hipótese de que o conto pode ser lido como uma alegoria do encontro entre a força física do jagunço e o poder simbólico encarnado pelo médico, narrador do conto. Tal encontro explicita a invisibilidade da violência simbólica, tornada visível, no entanto, através literatura.

Palavras-chave: Guimarães Rosa; linguagem; poder; dominação; violência.

\begin{abstract}
The tale Famigerado, by João Guimarães Rosa, read from the sociological theory of Pierre Bourdieu, helps us to demonstrate that language is an instrument of domination and violence. We criticize the reading of the tale that defends the idea that illiteracy can be equivalent to the most primitive encounter with language. We insist on the thesis that the symbolic power permeates the relations of power, constituting and maintaining them. We conclude by supporting the hypothesis that the tale can be read as an allegory of the encounter between the physical force of the "jagunço" and the symbolic power incarnated by the doctor, narrator of the tale. Such an encounter makes explicit the invisibility of symbolic violence, made visible, however, through literature.
\end{abstract}

Keywords: Guimarães Rosa; language; power; domination; violence.

\footnotetext{
${ }^{1}$ Pesquisador do (L@gir/Fafich/UFMG). Bolsista CNPq 1A de produtividade em pesquisa. Professor Permanente do Programa de Pós-Graduação em Psicologia da UFMG (Área de Concentração: Estudos Psicanalíticos; Linha de Pesquisa: Conceitos Fundamentais em Psicanálise e Investigações no Campo Clínico e Cultura).
} 


\section{INTRODUÇÃO}

O enredo do conto Famigerado, de João Guimarães Rosa, é bastante simples: o jagunço Damázio vai até a casa do médico, narrador da estória, a fim de saber o significado da palavra "famigerado". Damázio, tendo sido assim alcunhado por um "moço do Governo" (ROSA, 1988, p. 15), quer certificar-se se tal palavra significa "desaforado, caçoável” (ROSA , 1988, p. 16). O médico-narrador explica-lhe que não, que "famigerado" significa "importante" (ROSA, 1988, p. 16). Satisfeito, o visitante vai embora.

Do ponto de vista estético-literário, o conto é um dos exemplos mais bem acabados do estilo roseano, que, segundo Franklin de Oliveira (1991), explode a linguagem consuetudinária, desarticula a sintaxe tradicional e subverte a semântica dicionarizada. Aqui fica evidente que, em Rosa, "a palavra perdeu sua característica de termo, entidade de contorno unívoco, para converter-se em plurissigno, realidade multisignificativa." (OLIVEIRA, 1991, p. 180). Todas essas características aparecem nesse conto. De maneira suplementar, elas aparecem de forma metaliterária, isto é, trata-se de um conto que apresenta certa concepção de linguagem usando dessa mesma linguagem. Pretendo mostrar que essa característica metatextual é fundamental para se compreender o sentido de Famigerado.

Já do ponto de vista sociológico, é quase imediata a interpretação dessa estória. Trata-se de uma alegoria sobre como a linguagem constitui barreira social, como ela serve para humilhar e dominar as pessoas, como é possível excluir alguém apenas com o uso do saber. Trata-se, ainda, de mostrar claramente que todo o poder deste jagunço violento é ameaçado por um outro poder, bem menos visível, que é o poder simbólico, o poder da palavra. Esta contraposição de formas de poder ajuda a perceber a fragilidade da violência física - que, claro, também nunca deixa de ter sua dimensão simbólica - e o ilimitado poder da violência simbólica. É possível, como pretendo demonstrar, a partir da teoria de Pierre Bourdieu, lançar novas luzes sobre a fortuna crítica desse conto.

\section{O PROSAICO INSÓLITO}

O início do conto sugere que encontraremos uma estória absurda: "Foi de incerta feita - o evento. Quem pode esperar coisa tão sem pés nem cabeça?" (ROSA, 1988, p. 13). Um pouco mais adiante, o narrador adjetiva o evento: "insolitíssimo". Todo esse suspense, no entanto, destoa do caráter prosaico do que será narrado efetivamente, afinal, não há nada de estranho ou insólito em perguntar para alguém que julgamos mais sábio o significado de uma palavra. A questão que decorre dessa aparente contradição é: será que o narrador não gostaria justamente de apontar o estranho em uma situação familiar?

Acontece tal como em alguns contos de fada: mostrar uma situação banal de tal forma a reconhecermos nela algo que não víamos antes, algo tão comum que já havia se tornado invisível. Ora, não seria assim a relação do homem com a linguagem? De tal forma imersos na palavra, de tal forma constituídos por ela, não percebemos o nosso nãosaber e o quão somos atravessados pelo sem-sentido. A mistura do insólito e do prosaico se dá nessas situações nas quais o hábito tornou invisível a dominação. Mostrar o óbvio causa, de fato, sensação de estranheza. Algo como o estranho-familiar, proposto por 
Freud: algo que estava recalcado, de repente, vem à tona. No caso, o que é recalcado é o fato de a linguagem ser um instrumento de dominação bastante eficiente.

\section{IMPERMEABILIDADE FÍSICA}

Os primeiros quatro parágrafos do conto são dedicados à chegada e à descrição do tropel do jagunço Damázio. Os quatro cavaleiros ruidosos contrastam com o "arraial de todo tranquilo" (ROSA, 1988, p. 13). Em especial o cavaleiro da frente, Damázio, que parecia ter saído e vindo para "morrer em guerra" (ROSA, 1988, p. 13). Os outros três companheiros do jagunço também destoavam: "Semelhavam a gente receosa, tropa desbaratada, sopitados, constrangidos - coagidos, sim.” (ROSA, 1988, p. 13). Damázio exercia claro poder sobre os outros três: "Os três seriam seus prisioneiros, não seus sequazes." (ROSA, 1988, p. 13). A conclusão do narrador é rápida: “Aquele homem, para proceder da forma, só podia ser um brabo sertanejo, jagunço até na escuma do bofe." (ROSA, 1988, p. 13). Este qualificativo hiperbólico "até na escuma do bofe" marca claramente o julgamento do narrador quanto à figura assustadora de Damázio. A impressão que se tem é que tal qualificativo torna impossível qualquer tipo de contato ameno com o jagunço. Como se ele fosse impermeável ao tipo de contato que não fosse "brabo". Mais adiante, um novo julgamento: "Sei desse tipo de valentão que nada alardeia, sem farroma. Mas avessado, estranhão, perverso brusco, podendo desfechar com algo, de repente, por um és-não-és." (ROSA, 1988, p. 14). Trata-se, portanto, segundo o narrador, de alguém em quem não se pode confiar, pois que é imprevisível. É o sujeito pelo avesso, mais que estranho, "estranhão", mais que brusco, "perverso brusco".

A descrição do jagunço e da reação que ele provoca no médico é interrompida por uma frase de Damázio: "Eu vim perguntar a vosmecê uma opinião sua explicada..." (ROSA, 1988, p. 14). A formalidade do "vosmecê" e a aparente humildade de ignorante contrastam com a descrição horripilante do valentão. Começa, aqui, a inversão da hierarquia: o poder começa a mudar de lugar, ele passa do físico para o simbólico, da força para o saber. Se é possível comparar a narrativa do conto com um movimento pendular, esse é o ponto de subida para o outro lado, o ponto zero que marca a passagem do polo da dimensão física da violência simbólica para o polo linguístico da violência simbólica. É nesse momento que o narrador diz começar a se organizar "muito de macio, mentalmente" (ROSA, 1988, p. 14). O foco passa a ser o mental, e não mais o físico.

Apesar de começar a se organizar, a descrição que o narrador faz do jagunço continua assustadora: "Carregara a celha. Causava outra inquietude, sua farrusca, a catadura de canibal. Desfranziu-se, porém, quase que sorriu." (ROSA, 1988, p. 14). Ele fecha a cara, aproximando as sobrancelhas. Sua aparência enfarruscada, isto é, "escura, sombria" (MARTINS, 2001, p. 223), chega a ser comparada à de um canibal, mas ela se desfaz. Observe-se ainda a aliteração destas três frases: o "ca-" se repete nas duas primeiras, como que batendo. Depois, com o sorriso, é "amaciado" em "qua-". O quase sorriso talvez já seja a marca da humildade, do outro lugar que Damázio vai ocupar frente ao médico, que detém o saber.

A seguir, temos mais um elemento que parece mostrar a ambivalência do narrador diante de Damázio. Ele nota as "armas alimpadas" e percebe que "sua máxima violência podia ser para cada momento" (ROSA, 1988, p. 14), no entanto, o médico qualifica: "O 
chapéu sempre na cabeça. Um alarve. Mais os ínvios olhos" (ROSA, 1988, p. 14). Qual o sentido de "alarve" aqui? "Arábico", "rude" ou "idiota"? Seria menção ao turbante dos árabes? $\mathrm{Ou}$, além disso, o narrador se vale da polisignificância do adjetivo para qualificar o jagunço de forma pejorativa? Os olhos ínvios, isto é, intransitáveis, retomam a sensação que tivemos na primeira descrição de Damázio. Como se ele fosse impermeável, de difícil acesso.

O importante é notar que esse clima de suspense provocado pelo medo do narrador será mantido durante quase todo o conto. Ele só é rompido quando Damázio dirige sua questão ao médico. Esse é o ponto de virada, por assim dizer, no movimento pendular que detecto na narrativa.

\section{PODER SIMBÓLICO}

Um dos aspectos mais importantes de Famigerado é seu caráter metalinguístico. Não apenas por falar sobre o significado de uma palavra, mas, também, por trazer à baila expressões, neologismos e brincadeiras com o significante, que chamam a atenção do leitor para o papel da linguagem.

Para Bento Prado Jr. (2000, p. 174-175), a estrutura do conto se funda na relação crucial entre o analfabetismo e a escrita. $\mathrm{O}$ autor lembra que a estrutura do conto é semelhante àquela de Grande Sertão: Veredas, na medida em que ambos abrem espaço de comunicação entre dois mundos: "letrados e citadinos" (PRADO JR., 2000, p. 177). Aqui, como lá, um jagunço se dirige a um letrado para que ele dê sentido à sua dúvida: o que é famigerado, num caso, se o diabo existe, no outro.

Prado Jr. adverte que o analfabetismo não deve ser interpretado como algo, a princípio, negativo. O crítico sugere ver a positividade desse fenômeno: "Ao tornar possível a questão crucial (o que é o que é), o analfabetismo nos devolve a uma perplexidade diante do destino de que nos afastara a falsa sabedoria sedimentada nos dicionários." (PRADO JR., 2000, p. 177). Em outras palavras, Prado Jr. considera que o analfabeto, representado por Damázio, expressa o acesso a uma dimensão "esquecida e recalcada da própria linguagem" (PRADO JR., 2000, p. 177). Simetricamente, o saber letrado é um saber domesticado que perdeu o contado com a Escritura, isto é, com a linguagem "na condição de sujeito", "um Lógos mais primitivo, anterior a toda letra" (PRADO JR., 2000, p. 177). O crítico ainda lembra que tal analfabetismo não é literal, pois tem como função justamente revelar aquela dimensão recalcada da linguagem.

A interpretação de Bento Prado Jr. deve ser questionada. Apontar para a positividade do analfabetismo nos parece perigoso. Pensemos em sua negatividade antes de criticarmos tal interpretação. Para explicar a negatividade dessa posição, é preciso ter claro o que Pierre Bourdieu concebe como poder simbólico. Antes disso, porém, gostaria de citar na íntegra um trecho do artigo de Prado Jr. no qual ele explicita de maneira clara sua tese:

se é a própria linguagem, em sua dimensão própria, e não na transparência do signo, que é trazida à luz nessa estranha prosa, é compreensível que a linguagem se contorça para auscultar suas próprias entranhas. O recurso aos modelos da linguagem rústica não é o fruto de uma escolha ocasional: essa linguagem, que desconhece a codificação 
estrita de uma gramática que visa à eficácia operacional, é privilegiada para quem quer retornar àquele brilho das palavras que precede toda ação e prefigura as nervuras do imaginário. É o analfabeto, como o poeta, que consulta o volume interno das palavras, que interroga as franjas que a cercam, na esperança de alimentar a sua sabedoria. Aquém da escrita é que se pode encontrar uma experiência da linguagem semelhante àquela que a literatura procura restituir: esperança de captar, no puro movimento das palavras, no domínio exíguo que instauram, a verdade do mundo e da experiência. Não, certamente, que esse retorno à linguagem rústica, operado pela literatura, recupere essa experiência originária: não é o homem que se engolfa novamente numa linguagem que o ultrapassa e que o precede, mas é o homem que se destrói e perde sua alma, através da escrita, ao construir esse "modelo" de linguagem em "estado natural". Nesse movimento pelo qual a linguagem abandona a sua função comunicativa, para tornar-se valor e palavra pensante, ela passa a coincidir com o próprio Ser. (PRADO JR., 2000, p. 197-198)

Citei longamente a passagem de Prado Jr. porque é a partir de sua tese que apresentarei a minha. É preciso deixar claro que concordo com o autor no que me parece fundamental em sua interpretação: há, em Famigerado, uma preocupação em mostrar o poder da linguagem, poder de constituir o ser, de "instaurar a verdade do mundo" (PRADO JR., 2000, p. 198). Penso, entretanto, que parar a análise do texto nesse ponto é perder um de seus aspectos cruciais. Como disse, é preciso lembrar a negatividade desse elemento rústico, analfabeto, imerso na dúvida e no enigma da palavra, perdido diante do sem-sentido do signo. É preciso fazer um movimento dialético entre esse analfabeto apresentado por Prado Jr., como alegoria desse retorno às origens da palavra, e um outro analfabeto, qual seja, o exilado da língua, aquele que se vê, não raro, paralisado, como diante da Esfinge, frente à letra. Se é verdade que a gramática petrifica a linguagem, é também verdade que é através dela, da regra culta, que se tem acesso aos tesouros da palavra e a alguns de seus mais eficazes poderes. Aqui também é preciso um movimento dialético. Entre a gramática que faz calar a "vida" da língua e a gramática que dá "vida" à palavra.

É possível compreender bem o que designo como negatividade do analfabetismo a partir da noção de poder simbólico, tal como articulada por Bourdieu. Para o sociólogo francês, tal poder é, em grande medida, invisível. Tanto os que exercem ou os que estão a ele submetidos não se apercebem de seu exercício. Isso se dá porque os sistemas simbólicos, como instrumentos de comunicação e de conhecimento, são, ao mesmo tempo, estruturados e estruturantes. O poder simbólico é estruturado de tal forma a estruturar as formas de se compreender o mundo e de se comunicar. Por exemplo, a gramática estrutura a língua de tal forma que o que se fala e o que se dá a entender não seria possível de outra forma sem essa "grade". Por sua vez, tendemos a corrigir e a adequar nosso conhecimento e o sentido do mundo também a essa "grade". É nesse sentido que Bourdieu assevera:

é enquanto instrumentos estruturados e estruturantes de comunicação e de conhecimento que os "sistemas simbólicos" cumprem a sua função política de instrumentos de imposição ou de legitimação da dominação, que contribuem para assegurar a dominação de uma classe sobre outra (violência simbólica) dando o reforço da sua própria força às relações de força que as fundamentam e contribuindo assim, segundo a 
expressão de Weber, para a "domesticação dos dominados". (BOURDIEU, 2006, p. 11)

A passagem acima mostra claramente o caráter circular do poder simbólico. A imagem de um analfabeto perguntando o sentido de uma palavra exemplifica bem essa circularidade: o poder instituído representado pelo dicionário é reforçado por aquele excluído do saber estruturado pela escrita. É justamente por estar excluído dele que o sujeito se submete a ele.

Para Bourdieu, há uma luta simbólica para impor a definição do mundo social de acordo com interesses de classes sociais. Essa luta pode ser mais ou menos visível. Quanto mais legítimo um conhecimento parecer, isto é, quanto mais um sistema simbólico conseguir escamotear suas origens arbitrárias, mais invisível ele será. $\mathrm{O}$ dicionário, para continuarmos no exemplo suscitado por Famigerado, não parece impor nada a ninguém, mas, visto sob o ângulo da constituição de um sistema simbólico, tratase de uma rígida formatação do saber.

O poder simbólico como poder de constituir o dado pela enunciação, de fazer ver e fazer crer, de confirmar ou de transformar a visão do mundo e, deste modo, a ação sobre o mundo, portanto o mundo; poder quase mágico que permite obter o equivalente daquilo que é obtido pela força (física ou econômica), graças ao efeito específico de mobilização, só se exerce se for reconhecido, quer dizer, ignorado como arbitrário. (BOURDIEU, 2006, p. 14)

O universo de Damázio, como vimos nas descrições que o narrador faz dele, é o da força física. Construído dessa forma, o personagem permite ver com mais clareza o poder simbólico ao qual está contraposto e submetido. Quando o jagunço pede ao seu interlocutor que garanta sua resposta com a "mão na Escritura" (ROSA, 1988, p. 16), ele não só mostra que aceita esse poder como, também, que está submetido a ele. Mais uma vez, o narrador brinca com a ambiguidade semântica do significante: afinal, "Escritura", além do livro sagrado dos cristãos, aponta também para o escrito, o saber legítimo.

Ainda no que diz respeito à legitimidade do saber, no conto isso aparece de forma clara na seguinte passagem.

Lá, e por estes meios de caminho, tem nenhum ninguém ciente, nem têm o legítimo - o livro que aprende as palavras... É gente pra informação torta, por se fingirem de menos ignorâncias... Só se o padre, no São Ão, capaz, mas com padres não me dou: eles logo engambelam.... (ROSA, 1988, p. 15-16)

Damázio explicita três lugares legítimos de saber: alguém "ciente", o dicionário e o padre. Na ausência dos dois primeiros e na desconfiança depositada no terceiro, restalhe procurar o médico das redondezas. Essa situação permite ver a tese de Bourdieu: "O que faz o poder das palavras e das palavras de ordem, poder de manter a ordem ou de a subverter, é a crença na legitimidade das palavras e daquele que as pronuncia, crença cuja produção não é da competência das palavras" (BOURDIEU, 2006, p. 15). 
Quanto à origem da legitimidade da palavra, aliás, o conto é magistral em mostrar algumas de suas faces: lembremos que é um "moço do governo" (ROSA, 1988, p. 16) que adjetiva Damázio de "famigerado", ou seja, a palavra tem um poder porque é enunciada a partir de um lugar específico. "O poder simbólico", lembra Bourdieu, "é uma forma transformada, quer dizer, irreconhecível, transfigurada e legitimada, das outras formas de poder [...]" (BOURDIEU, 2006, p. 15). Tanto o lugar da ofensa (moço do governo) como o lugar do saber (médico-narrador) são lugares estruturados e estruturantes na produção desse saber-poder simbólico ao qual Damázio se vê submetido.

Gostaria de articular agora a dialética, que propus mais acima, entre as posições de Prado Jr. e Bourdieu. Por um lado, vimos que Prado Jr. lê o analfabetismo como um tipo de alegoria da linguagem pré-gramatical, uma linguagem dos "poetas". Por outro lado, Bourdieu lembra que a linguagem é um dispositivo de poder. Ela não apenas estrutura o conhecimento, como também condiciona o acesso a ele. Gostaria de negar, no sentido dialético, a posição de Prado Jr., lembrando que o que o analfabetismo metaforiza não é uma linguagem originária, mas a origem arbitrária do signo e de sua estruturação.

A primeira síntese possível da dialética que proponho pode ser resumida na seguinte ideia: nascemos imersos na linguagem, mas não nascemos falando. Prado Jr. está certo em lembrar que a linguagem vai muito além da comunicação, mas é preciso evitar a ideia de que a linguagem possa ser separada dos jogos de poder que a estruturam e que ela estrutura. É preciso lembrar - e o conto de Rosa nos ajuda nessa tarefa - que a linguagem jamais poderá ser independente de sua produção social. O "Lógos primitivo, anterior a toda letra", sobre o qual nos fala Prado Jr. (2000, p. 177), não existe, mas pode ser entendido como esse lugar e esse momento nos quais, de forma fugaz, toma-se consciência do poder simbólico e de sua origem arbitrária. E é justamente aqui que entra a literatura. A literatura pode mostrar como isso acontece. O conto Famigerado é especialmente eficaz nesse sentido, como pretendo mostrar na próxima seção, interpretando seu caráter metalinguístico.

\section{METALINGUÍSTICA}

De três maneiras o metalinguístico aparece em Famigerado: através dos neologismos; nos sinais gráficos do texto; e na escolha de palavras pouco comuns. Essas três faces compõem um só todo: chamam a atenção para os mais diversos aspectos da linguagem. Em primeiro lugar, mostra como se pode inventar a palavra. Em segundo, como as dimensões escrita e oral podem se contrapor e se relacionar. A aliteração serve, em grande parte, a esses dois primeiros propósitos. Finalmente, a narrativa mostra como há diversos graus de acesso ao campo simbólico. Gostaria de mostrar com exemplos cada um desses três pontos.

\subsection{BRINCAR COM A PALAVRA}

Há diversas brincadeiras com a palavra e com a letra ao longo do conto. Tome-se, por exemplo, a descrição de Damázio como “o oh-homem-oh” (ROSA, 1988, p. 13). É importante analisar essa expressão de perto. Além de reforçar o espanto que ele causa no médico-narrador, chama atenção a brincadeira com as letras "oh", que na primeira sílaba 
de "homem" são invertidas, sofrendo nova reversão na interjeição repetida ao final. Mais adiante, veremos que este procedimento narrativo semelhante será usado na frase " $\mathrm{O}$ medo O".

Perante o jagunço "estranhão", a reação do narrador, de extremo medo, é compreensível: "Senti que não ficava útil dar cara amena, mostras de temeroso. Eu não tinha arma ao alcance. Tivesse, também, não adiantava. Com um pingo no i, ele me dissolvia. $\mathrm{O}$ medo é a extrema ignorância em momento muito agudo. $\mathrm{O}$ medo $\mathrm{O}$. O medo me miava." (ROSA, 1988, p. 14). Essa descrição da impotência do médico frente à capacidade de violência do jagunço é de extrema importância. Primeiramente, mostra um tipo de poder que será, em breve, desbancado por um outro poder. Fica clara aqui a dissimetria entre os dois personagens. Um é bem mais poderoso que o outro. Veremos que, até o final desse encontro, essa dissimetria vai se inverter radicalmente.

O segundo ponto importante a se notar na descrição dos afetos causados pela presença de Damázio no médico é seu caráter metalinguístico. Como que anunciando o que vai acontecer no restante da estória, o narrador se vale de alguns recursos para colocar a linguagem em evidência: (a) "um pingo no i": a expressão linguística usada aqui no sentido de rapidez, velocidade, já aponta para a língua escrita, culta. A "dissolução" do sujeito se dá de formas diferentes: o "pingo no i”, aqui, é a violência física, e mais adiante, será o poder simbólico; (b) "O medo O": a grafia em maiúscula do segundo "O" provoca um efeito semiótico interessante, como se a palavra "medo" representasse o sujeito deste afeto, preso, encurralado, sem saída entre os dois buracos da letra "O". Procedimento semelhante já havia sido empregado em "oh-homem-oh", mais uma vez para chamar a atenção para a dualidade da linguagem: parte dela só é visível escrita. Se fossem apenas faladas, as frases perderiam este sentido suplementar tornado possível pela grafia; (c) finalmente, o narrador ainda usa o recurso da aliteração em "O medo me miava". O som do " $\mathrm{m}$ " que se repete faz a frase ganhar força no significante, abrindo-a para significados, a princípio, enigmáticos. O medo miava para ele ou nele? Fazia com que ele miasse? $\mathrm{O}$ medo seria, metaforicamente, como um gato agourento, um felino violento, ou seria ele, o médico medroso, um gatinho assustado? Todos esses significados se abrem, sem conclusão possível. Sobressai a aliteração "me", "mi", "mi” e o som "i", mesmo em "me", que se lê "mi", repetido em "miava". O "i" volta agora como som, e não como letra, na expressão "com um pingo no i", tornando ainda mais complexo o apanhado metalinguístico desta breve passagem.

\subsection{A ESCRITA E A FALA}

Os sinais gráficos da escrita no conto são importantes, pois parecem contribuir para seu caráter metalinguístico. $\mathrm{O}$ exemplo mais claro são as aspas que marcam as frases de Damázio. Por que as aspas distinguem as falas do jagunço das do médico? Mais uma vez, assim como na frase "O medo O", o escritor usa um recurso da língua escrita, uma marca gráfica, para dizer algo. As aspas serviriam apenas para acentuar o caráter anedótico do caso? Ou para mostrar ao leitor que ele está transcrevendo o que ouviu, dando assim maior verossimilhança ao relato? Ou, ainda, poderíamos interpretar as aspas como marca de uma diferença discursiva? Neste sentido, as aspas seriam um tipo de limite, imposto pela linguagem chamada culta ao discurso do outro (do "estranhão"), que se quer preservar ou capturar. Ficam demarcadas duas vozes, de tal forma a se estabelecer 
uma hierarquia entre elas, pois é o discurso do médico aquele a apreender o discurso do jagunço.

Talvez estejamos diante de um dos problemas mais agudos da literatura voltados para a alteridade. Afinal, a reprodução literária do discurso de um analfabeto não é o discurso deste analfabeto, é a sua apropriação. Como, então, fazer falar o excluído? Como dar voz ao pobre, ao analfabeto, às minorias? E se por acaso escrevessem romances, contos, novelas, estariam eles falando com sua própria voz ou já estariam usando a linguagem deste outro que o marginalizou? Para Pierre Bourdieu, lembremos, "as aspas são um dos marcadores mais potentes da negação e da passagem à ordem da economia simbólica" (BOURDIEU, 1996, p. 190). Ou seja, nega-se a igualdade entre as partes no diálogo e segrega-se o discurso do outro.

Em nenhum momento do conto, entretanto, a relação entre a escrita e a oralidade é tão forte quanto no momento em que o narrador, pela primeira vez, explica o que é famigerado: “Famigerado é inóxio, é ‘célebre', 'notório', 'notável'..." (ROSA, 1988, p. 16). Para quem ouve e não sabe o significado de inóxio, tal adjetivo pode entrar na lista de sinônimos arrolados pelo médico. Para o leitor, as aspas nos outros adjetivos diferenciam o qualificativo de famigerado de seus sinônimos. Nessa frase, fica explícito que o jogo de poder já se inverteu: as palavras difíceis e essa pequena armadilha entre o qualificativo e o sinônimo dão mostras da passagem do poder físico para o poder simbólico.

\subsection{A PALAVRA DIFÍ́CIL}

Ao longo do conto, palavras pouco comuns aparecem com frequência. Sabemos que há, em toda obra de Guimarães Rosa, um imenso trabalho com a linguagem, que vai desde a procura por palavras pouco usadas até os neologismos. Nesse conto, todavia, esse trabalho se mostra particularmente fecundo a ponto de tornar plausível uma leitura que o tome como metalinguístico - ou seja, trata-se de um trabalho com a linguagem para falar sobre o que a linguagem faz. Afinal, não é semelhante o que sentimos, quando encontramos "alarve" ou "ínvios", ao que sente Damázio, ao encontrar "famigerado"? Tal como o jagunço, também reconhecemos que parte da linguagem nos escapa; assim como ele, recorremos a alguém (ao Aurélio, ao Houaiss, ao Léxico de Nilce Martins) que possa nos esclarecer a dúvida. Fazer o leitor ir ao dicionário pode ser visto como a tentativa do escritor em reproduzir de forma alegórica o que está narrando. É como se o texto fizesse ao leitor o que o "moço do governo" fizera a Damázio.

Depois de formular sua questão, o médico responde com uma pergunta: "Famigerado?". A palavra vem grafada em itálico - apenas uma vez no conto ela aparece sem essa marca gráfica - como que pra reforçar o estranhamento que ela causa. Por que a pergunta? É para se certificar de que é essa mesma a palavra ouvida? Se é essa a intenção, a resposta do jagunço é rápida: "Sim senhor...". Parece, todavia, que era ainda o medo que impedia o doutor de dar no "pau da peroba" o significado do enigma: "Habitei preâmbulos. Bem que eu me carecia noutro ínterim, em indúcias. Como por socorro, espiei os três outros, em seus cavalos, intugidos até então, mumumudos." (ROSA, 1988, p. 16). Uma vez mais, palavras incomuns são invocadas, o verbo "habitar" é usado de forma que parece pedante. O "in", que se repete em "ínterim", "indúcias" e "intugidos", 
faz pensar que é proposital esse excesso, esse discurso empolado do doutor. Daí supor outra interpretação à pergunta.

Ao perguntar "Famigerado?", o médico já começa a inverter as posições de poder. Se, antes, era o poder físico que estava em evidência, a partir de agora, é o poder simbólico que começa a dar as cartas. E o narrador faz o próprio leitor sentir na pele o que é não saber o significado das palavras. "Intugido", por exemplo, não se encontra nem no Houaiss, nem no Aurélio. Apenas no Léxico de Guimarães Rosa descobrimos que a palavra vem de "in- + tugir" e significa falar baixo, murmurar. Há ambiguidade, porém, pois "tugir" é usado na frase feita "sem tugir, nem mugir" (ROSA, 1988, p. 14), que significa "sem falar nada". Por isso, restam dúvidas: o neologismo "mumumudos", que repete três vezes o estado dos três cavaleiros, significa que falavam baixo ou que estavam mudos? E o que dizer da semelhança com um gaguejar produzido em "mumumudos"? Não é semelhante ao gaguejar da frase "o medo me miava" (ROSA, 1988, p. 14), referente ao próprio narrador?

Se, nas brincadeiras com "oh-homem-oh" e "O medo O", o narrador chama nossa atenção para a dimensão escrita da língua, em "o medo me miava" e "mumumudos", nossa atenção se volta para a dimensão oral da linguagem. É como se o narrador desejasse fazer notar as muitas dimensões da linguagem ao longo do conto: a oral, a escrita, a do pobre, a do dicionário, etc., como que para evitar a interpretação rasteira desta estória. Não se trata apenas da divisão entre a língua do jagunço versus a língua do médico. As fronteiras são mais fluídas: mesmo o leitor culto tem dificuldade com muitas palavras no conto. Isso parece mostrar que a linguagem não é tão polarizada assim, que, mesmo dentro de um campo linguístico específico há diferenças, há exclusão de alguns, há ambiguidade.

\section{FAMIGERADO}

Após dizer seu nome, Damázio tem dificuldades em formular a questão que o leva até o doutor. Ele lembra que apareceu em sua região "um moço do Governo, rapaz meio estrondoso", fala ainda de "travados assuntos, insequentes", e, finalmente, pergunta: "Vosmecê agora me faça a boa obra de querer me ensinar o que é mesmo que é: fasmisgerado... faz-me-gerado... falmisgeraldo... familhas-gerado...?" (ROSA, 1988, p. 15). Mais uma vez, o escritor faz uso de um recurso gráfico, o itálico, para acentuar a alteridade da fala. Os quatro significantes tornam evidente a distância entre a palavra de onde provêm e o sentido que ela ganha para quem a escuta. A palavra quase se perde, sua morfologia não resiste ao trânsito entre o remetente e o destinatário. Dos quatro significantes elencados por Damázio dois parecem uma apreensão de "famigerado" a partir da linguagem que já possui: "faz-me-gerado" e "familhas-gerado". As outras duas palavras guardam apenas semelhança homofônica. Nem pelo som, nem por aproximação Damázio consegue dar sentido ao adjetivo enigmático.

Damázio, então, insiste: "Agora, se me faz mercê, vosmecê me fale, no pau da peroba, no aperfeiçoado: o que é o que é, o que já lhe perguntei." (ROSA, 1988, p. 16). A maneira com a qual formula sua demanda merece atenção. "O que é o que é" parece remeter ao universo infantil, afinal, as charadas assim formuladas são voltadas principalmente para as crianças. Obviamente, os que participam da estória narrada não 
são crianças. Damázio, entretanto, ocupa uma posição infantil fundamental: ele se dirige a um outro para solucionar o enigma da palavra e seus efeitos.

Agora é possível interpretar melhor por que o narrador diz que o evento foi "de incerta feita" e por que o mesmo é descrito como "insolitíssimo". É incerto porque a dúvida com relação à palavra acontece em quaisquer lugar e momento. É insólito porque é raro tomar consciência e enfrentar as barreiras sociais do poder simbólico. É próprio da economia simbólica ser estruturada de tal forma a fazer com que as dúvidas nem cheguem a aparecer. Se aparecem, também há uma série de estruturas sociais que impedem a formulação dessa questão a lugares que possam efetivamente esclarecê-la.

\section{O VERIVÉRBIO}

"Só tinha de desentalar-me. O homem queria estrito o caroço: o verivérbio." (ROSA, 1988, p. 16). Na última frase, a forte aliteração - ri, tri, ro, ri, ér - e o neologismo chamam nossa atenção para o trabalho com a linguagem. O que significa "verivérbio"? É a conjunção de "vero" e "verbo", isto é, o vero verbo, a palavra verdadeira: "o termo exato, o sentido preciso da palavra" (MARTINS, 1991, p. 521). Num conto que versa sobre o significado da palavra, este neologismo merece ser destacado. A questão que se impõe é: o verivérbio existe? É possível a palavra verdadeira, exata? É possível o sentido preciso? O que se mostra no conto não é justamente a possibilidade de encontrar muitos sentidos para as palavras e para a linguagem?

A primeira resposta do médico não desfaz a dúvida de Damázio. Ao contrário, faz com que ele retribua a profusão de palavras com perguntas: "Vosmecê mal não veja em minha grossaria no não entender. Mais me diga: é desaforado? É caçoável? É de arrenegar? Farsância? Nome de ofensa?" (ROSA, 1988, p. 16). A questão, portanto, vai além de uma preocupação com o sentido estrito do termo, com a troca neutra de palavras - célebre, notório, notável. O ponto é averiguar se é ofensa ou não, se merece ou não vingança.

Neste ponto, a interpretação do texto sofre um deslocamento interessante. Não é apenas uma alegoria sobre os sentidos da linguagem que nos escapam. Aqui, fica evidente que "a linguagem não está fora do homem, não é uma simples ferramenta a que possa recorrer. A linguagem está no homem da mesma maneira que o homem está na linguagem" (PORTELLA, 1991, p. 201). Assolado pela dúvida trazida pela palavra, Damázio é o sujeito tomado pela linguagem. Sua estória permite ver o que os sentidos do verbo fazem conosco e o que nos fazem fazer, em outras palavras, é uma estória sobre o efeito performativo das palavras.

O doutor, entretanto, parece recusar em entregar a Damázio o "estrito caroço". Ele responde, novamente usando palavras incomuns: "Vilta nenhuma, nenhum doesto. São expressões neutras, de outros usos..." (ROSA, 1988, p. 16). Aqui, a situação inicial já se inverteu completamente. É o doutor que parece torturar o jagunço. Sabe o significado, mas se recusa a entregar. Parece mesmo caçoar da dificuldade do outro. Agora quem é "ínvio" é o doutor, não mais os olhos do jagunço. O intransitável, o impermeável é criado pela linguagem. 


\section{FALA DE POBRE}

Damázio, porém, insiste: "Pois... e o que é que é, em fala de pobre, linguagem de em dia-de-semana?" (ROSA, 1988, p. 16). Esta frase parece ter um forte traço metatextual. O conto é sobre esta diferença entre linguagens: a fala do pobre e a fala do doutor, a linguagem de em dia-de-semana e a linguagem de dicionário ${ }^{2}$. O próprio texto em sua diegese e em sua morfologia brinca com esta dualidade. Vale-se do discurso de Damázio para fazer aparecer o discurso do pobre, usa os excessos do médico para mostrar o discurso de dicionário.

Só depois desta pergunta esclarecedora é que o doutor fala usando palavras que o jagunço poderia entender: "Famigerado? Bem. É: "importante", que merece louvor, respeito..." (ROSA, 1988, p. 16). Esta definição, sabemos, é parcial. O Houaiss lembra que o termo tem uso pejorativo: "tristemente afamado" (HOUAISS, 2001, s/p). Essa definição parcial volta a colocar em questão o "verivérbio". O médico talvez não explicite o caráter pejorativo do termo porque queira evitar que o jagunço mate o "moço do Governo". É mais a face pragmática da palavra o que interessa, não seu caráter semântico. Não deixa de ser verdade que famigerado significa famoso.

A importância do efeito pragmático do sentido da palavra é reforçada na pergunta de Damázio: "Vosmecê agarante, pra a paz das mães, mão na Escritura?" (ROSA, 1988, p. 16). "A paz das mães" é o efeito que o sentido produz. A "mão na Escritura" é a garantia de legitimidade deste sentido. O que se vê é o apelo a dois lugares de certeza na nossa cultura: o materno e o bíblico.

Se certo! Era para se empenhar a barba. Do que o diabo, então eu sincero disse:

- Olhe: eu, como o sr. me vê, com vantagens, hum, o que eu queria uma hora destas era ser famigerado - bem famigerado, o mais que pudesse!... - "Ah, bem!..." - soltou, exultante. (ROSA, 1988, p. 16)

Será mesmo "sincero" o médico? Sincero como o diabo? E o narrador, é sincero? Não nos parece. O médico dá apenas a metade do significado para evitar o pior e ainda diz que queria ser "bem famigerado". Observem ainda a frase: o "sr." e o "hum" contrastam. "Sr." é abreviatura, própria para a língua escrita. "Hum" é interjeição, própria da língua oral. Deve-se desconfiar da sinceridade deste narrador que tanto brinca com as ambiguidades da linguagem. À primeira vista, ele parece apenas querer evitar o pior, dizendo pela metade o significado de "famigerado", mas se examinarmos mais de perto, perceberemos que ele não só faz uso das "indúcias" que diz não fazer, como também, parece se aproveitar da situação para mostrar o funcionamento do poder que detém. E faz isso tanto com Damázio quanto com o leitor. Com o jagunço e com o leitor usa palavras difíceis, quase inacessíveis. De forma suplementar, ainda chama a atenção do leitor para as sutilezas dos sinais gráficos e da palavra escrita.

O último parágrafo do conto merece ser citado na íntegra:

\footnotetext{
${ }^{2}$ Um possível significado da expressão "linguagem de em dia-de-semana" faz referência ao latim das missas aos domingos. Faz sentido, no conto, pois o padre aparece como alguém que "engambela", talvez pelo uso dessa linguagem difícil, inacessível.
} 
Saltando na sela, ele se levantou de molas. Subiu em si, desagravavase, num desafogaréu. Sorriu-se, outro. Satisfez aqueles três: - "Vocês podem ir, compadres. Vocês escutaram bem a boa descrição..." - e eles prestes se partiram. Só aí se chegou, beirando-me a janela, aceitava um copo d'água. Disse: - "Não há como que as grandezas machas duma pessoa instruída!" Seja que de novo, por um mero, se torvava? Disse: - "Sei lá, às vezes o melhor mesmo, pra esse moço do Governo, era ir-se embora, sei não..." Mas mais sorriu, apagara-se-lhe a inquietação. Disse: - "A gente tem cada cisma de dúvida boba, dessas desconfianças... Só pra azedar a mandioca..." Agradeceu, quis me apertar a mão. Outra vez, aceitaria de entrar em minha casa. Oh, pois. Esporou, foi-se, o alazão, não pensava no que o trouxera, tese para alto rir, e mais, o famoso assunto. (ROSA, 1988, p. 16-17)

Em primeiro lugar, nota-se o efeito produzido pelo reconhecimento do sentido da palavra: o jagunço se transforma, chega a sorri. O prefixo "des-" marca o apaziguamento da angústia, a dissolução da angústia: "desgravava-se, num desafogaréu". Os três cavaleiros que acompanhavam Damázio são dispensados. Estavam ali apenas para testemunho. O ritual está completo. Não bastaria que apenas ele soubesse que não foi ofendido. Eram precisas testemunhas para espalhar a notícia. Novamente, o que se vê é um processo de legitimação do significado.

O elogio que Damázio faz ao médio é curioso: "Não há como que as grandezas machas duma pessoa instruída!". Parece misturar os dois universos, o do jagunço e o do médico. Como se Damázio, valendo-se de seus próprios parâmetros de medida, traduzisse a instrução em força física. É exatamente este tipo de tradução o que mostra o quão distante está o jagunço do reconhecimento do "estrito caroço" do poder simbólico.

Notemos ainda no último parágrafo a breve recaída de Damázio. Por via das dúvidas, era melhor "o moço do Governo" ir-se embora. Dá pra desconfiar se é mesmo boba a "cisma" que "azeda a mandioca". Se fosse, não seria preciso tantas medidas defensivas.

Por fim, na última brincadeira com o leitor, o narrador qualifica sua estória como "tese para alto rir", como um "famoso assunto". O que é que provoca o riso na estória? É a "cisma boba" que tivera o médico quando chegou até sua porta os quatro jagunços? Ou é a "cisma boba" de Damázio, atormentado pela falta de sentido de uma palavra? E por que o narrador usa "famoso" apenas com o leitor e não com Damázio? Talvez seja para mostrar, mais uma vez, que o verivérbio não há. Sempre há mais um sentido, um outro efeito inesperado que a palavra causa.

\section{CONCLUSÃo}

Para Guimarães Rosa, linguagem e vida são uma só e mesma coisa. A literatura, arte da linguagem, brota da vida e não pode jamais separarse dela. Uma pessoa que não faz da linguagem um espelho do seu próprio ser não chega a existir, e o escritor, mais do que ninguém, deve estar ciente disso. (COUTINHO, 1991, p. 202) 
Assim como na vida nos deparamos com o não-saber, a literatura também pode representar esse encontro. Famigerado pode ser lido, então, como uma alegoria desse reconhecimento de que vida e linguagem são uma só coisa. Se o leitor, assim como o protagonista da estória, sente dificuldade em apreender o sentido de algumas palavras é para metaforizar um processo infinitamente maior, que diz respeito ao próprio ser do humano, qual seja: o de que nossa existência é dada a partir e pela linguagem. Isso, no entanto, não quer dizer que haja uma linguagem. O que o conto permite ver é que as linguagens são muitas, os muitos jogos que podemos fazer com o signo estão intimamente ligados às estruturas de poder.

Ao distanciarmos o conto das interpretações heideggerianas que tem recebido, e ao tornar mais clara sua dimensão política, estamos seguindo a advertência de Pierre Bourdieu:

a destruição deste poder de imposição simbólico radicado no desconhecimento supõe a tomada de consciência do arbitrário, quer dizer, a revelação da verdade objetiva e o aniquilamento da crença: é na medida em que o discurso heterodoxo destrói as falsas evidências da ortodoxia, restauração fictícia da doxa, e lhe neutraliza o poder de desmobilização, que ele encerra um poder simbólico de mobilização e de subversão, poder de tornar atual o poder potencial das classes dominadas. (BOURDIEU, 2006, p. 15)

Damázio toma consciência apenas de que não sabe o sentido de uma palavra. Falta um passo: tomar consciência do que esse não-saber significa. Esse segundo passo é mais fácil para o leitor. Não se trata de ver o analfabetismo como um certo tipo de proximidade neutra ao Ser da Linguagem. É preciso compreender o discurso que porta o não-saber como esse heterogêneo que subverte o que o poder simbólico quer tornar invisível, recalcado: a linguagem é também, senão fundamentalmente, um instrumento de dominação.

\section{REFERÊNCIAS}

BOURDIEU, Pierre. O poder simbólico. 9a. ed. Trad. Bras. Rio de Janeiro: Bertrand Brasil, 2006.

Razões práticas: sobre a teoria da ação. Trad. Bras. Campinas: Papirus, 1996.

COUTINHO, Eduardo F. Guimarães Rosa e o processo de revitalização da linguagem. Em: COUTINHO, Eduardo F. (Org.). Guimarães Rosa. 2a . ed. Rio de Janeiro: Civilização Brasileira, 1991.

HOUAISS, A. Dicionário Eletrônico Houaiss da Língua Portuguesa. São Paulo: Objetiva, 2001.

MARTINS, Nilce Sant'Anna. O léxico de Guimarães Rosa. São Paulo: Edusp, 2001. 
OLIVEIRA, Franklin. Revolução roseana. Em: COUTINHO, Eduardo F. (Org.). Guimarães Rosa. 2a . ed. Rio de Janeiro: Civilização Brasileira, 1991.

PORTELLA, Eduardo. A estória cont(r)a a história. Em: COUTINHO, Eduardo F. (Org.). Guimarães Rosa. 2a ${ }^{\mathrm{a}}$ ed. Rio de Janeiro: Civilização Brasileira, 1991.

PRADO JR., Bento. O destino decifrado: linguagem e existência em Guimarães Rosa. Em: PRADO JR., Bento. Alguns ensaios: filosofia, literatura, psicanálise. 2a . ed. São Paulo: Paz e Terra, 2000. pp. 173-200.

ROSA, João Guimarães. Famigerado. Em: ROSA, João Guimarães. Primeiras estórias. Rio de Janeiro: Nova Fronteira, 1988. pp. 13-17.

Artigo recebido em: dezembro de 2017.

Aprovado e revisado em: março de 2018.

Publicado em: maio de 2018.

\section{Para citar este texto:}

BELO, Fábio Roberto Rodrigues. O impossível verivérbio: "Famigerado", de G. Rosa, como alegoria do poder simbólico. Entremeios [Revista de Estudos do Discurso, ISSN 2179-3514, on-line, www.entremeios.inf.br], Seção Temática [Discurso, arte e literatura - Parte I], Programa de Pós-Graduação em Ciências da Linguagem (PPGCL), Universidade do Vale do Sapucaí (UNIVÁS), Pouso Alegre (MG), vol. 16, p. 343-357, jan. - jun. 2018.

DOI: http://dx.doi.org/10.20337/ISSN2179-3514revistaENTREMEIOSvol16pagina343a357 